\title{
SOIL MINERAL NITROGEN IN SOIL UNDER INJECTION AND SURFACE APPLICATION OF SWINE SLURRY WITH NITRIFICATION INHIBITOR
}

Luiz Paulo Rauber ${ }^{1}$, Andréia Patrícia Andrade ${ }^{1}$, Álvaro Luiz Mafra ${ }^{1}$, Walter Santos Borges Júnior ${ }^{1}$, Daniel João Dall'Orsoletta ${ }^{1}$, Luciano Colpo Gatiboni ${ }^{1}$, Celso Aita ${ }^{2}$

${ }^{1}$ Universidade do Estado de Santa Catarina. E-mail: sr_roiber@yahoo.com.br; andreiapatricia74@yahoo.com.br; alvaro.mafra@udesc.br; waltersbjr@hotmail.com; dani.orsoletta@gmail.com; lgatiboni@gmail.com

${ }^{2}$ Universidade Federal de Santa Maria. E-mail: celsoaita@gmail.com

\section{ABSTRACT}

Management alternatives can minimize the negative impacts of swine slurry (SS) on the environment and improve its fertilizing effect. The objective of this study was to evaluate the application of SS and urea, associated with nitrification inhibitor dicyandiamide (DCD), on mineral $\mathrm{N}$ contents in no-tillage soil. The experiment was carried out on a Humic Dystrupept soil, in a randomized experimental block design with four replications, using a 2 x 5 factorial. The treatments were as follows: injected and surface SS application and urea and five sources of N, urea; urea + DCD; SS; SS + DCD and a control treatment with no N. The evaluation of ammonium and nitrate occurred during the maize crop seasons 2012/2013 and 2013/2014 and during the wheat crop in 2013, with soil sampling at depths of 0-5, 5-10 and $10-20 \mathrm{~cm}$. The injected application of SS + DCD increased the ammonium content by $65 \%$ compared to the surface application, at eight days in the 2012/2013 crop, preserving for longer the $\mathrm{N}$ in the ammoniac form. DCD use and the injection of both fertilizers were efficient in maintaining the ammonium for a longer period in the soil.

Keywords: Manure, fertilization, ammoniacal-N, losses of N

\section{NITROGÊNIO MINERAL NO SOLO COM APLICAÇÃO INJETADA E SUPERFICIAL DE DEJETO DE SUÍNOS COM INIBIDOR DE NITRIFICAÇÃO}

\section{RESUMO}

Alternativas de gerenciamento podem minimizar os impactos negativos da aplicação de dejetos líquidos de suínos (DLS) no meio ambiente e melhorar seu efeito fertilizante. O objetivo deste estudo foi avaliar a aplicação de DLS e ureia, associada à inibição da nitrificação diciandiamida (DCD), no conteúdo de $\mathrm{N}$ mineral em solo sem plantio direto. $\mathrm{O}$ experimento foi realizado em um Cambissolo 
Húmico, em um delineamento experimental em blocos casualizados com quatro repetições, utilizando um fatorial 2 x 5. Os tratamentos foram os seguintes: duas formas de aplicação (injetada e superfície de DLS e ureia) e cinco fontes de N (Ureia; Ureia + DCD; DLS; DLS + DCD e um tratamento de controle sem N). As avaliações de amônio e nitrato ocorreram durante as safras de milho 2012/2013 e 2013/2014 e durante a colheita de trigo em 2013, com amostragem de solo, nas profundidades de 0-5, 5-10 e 10-20 cm. A aplicação injetada de DLS + DCD aumentou o teor de amônia em 65\% em comparação com a aplicação em superfície, em oito dias na safra 2012/2013, preservando por mais tempo o N na forma amoniacal. O uso de DCD e a injeção de ambos os fertilizantes foram eficientes na manutenção do amônio por um período mais longo no solo.

Palavras-chave: Adubo, fertilização, N-amoniacal, perdas de N

\section{INTRODUCTION}

The development of new technologies can reduce the polluting potential of swine slurry (SS) and improve its efficiency as a source of nutrients, especially nitrogen $(\mathrm{N})$ for crops. Technologies such as injection and nitrification inhibitors may reduce $\mathrm{N}$ losses and increase $\mathrm{N}$ supply to plants improving agricultural use of SS (DELL et al., 2011).

Among the existing nitrification inhibitors, dicyanodiamide (DCD) can be mixed with different $\mathrm{N}$ sources, such as animal manure to reduce nitrate $\left(\mathrm{NO}_{3}{ }^{-}\right)$leaching and nitrous oxide $\left(\mathrm{N}_{2} \mathrm{O}\right)$ emission into the atmosphere (ZAMAN \& BLENNERHASSETT, 2010). This inhibitor blocks the action of the ammonia-monooxygenase enzyme, reducing the oxidation of ammonium to nitrite, in the first stage of nitrification, maintaining for a longer time $\mathrm{N}$ in the ammoniac form in the soil (SINGH \& VERMA, 2008). However, the magnitude of this effect when DCD is added to animal manure is dependent on factors such as soil moisture and temperature (SUBBARAO, 2015).

The SS incorporation can increase the mineral $\mathrm{N}$ content in the soil in relation to the surface application, besides increasing organic $\mathrm{N}$ mineralization rate from soil and from manure (GIACOMINI \& AITA, 2008). Thus, subsurface injection of SS in the soil can be an alternative for its use in no-tillage system (MISSELBROOK et al., 2002).

The objective of this work was to evaluate injected and surface application of SS and urea, combined with nitrification inhibitor (DCD) on mineral $\mathrm{N}$ concentrations of a soil in maize and wheat crops under no-tillage. 


\section{MATERIAL AND METHODS}

The experiment was carried out in Lages, in the state of Santa Catarina, Brazil, located at $27^{\circ} 49^{\prime} 00^{\prime \prime}$ south latitude and $50^{\circ} 35^{\prime} 50^{\prime \prime}$ west longitude, with an average altitude of $892 \mathrm{~m}$. The climate is humid subtropical $(\mathrm{Cfb})$, according to Köppen, with well distributed rains and mean annual precipitation and temperature of $1,400 \mathrm{~mm}$ and $15.6^{\circ} \mathrm{C}$, respectively (EMBRAPA, 2004).

The work was carried out from November 2012 to April 2014 on an Humic Dystrupept soil (EMBRAPA, 2004), presenting in the 0-20 cm layer, the following chemical and physical properties, analyzed before the experiment establishment, according to Tedesco et al. (1995) and Embrapa (1997), respectively: $\mathrm{pH}$ water 5.4; $\mathrm{Al}: 0.7 \mathrm{cmol}_{\mathrm{c}} \mathrm{dm}^{-3}$; $\mathrm{Ca}: 7 \mathrm{cmol}_{\mathrm{c}} \mathrm{dm}^{-3} ; \mathrm{Mg} 4.2 \mathrm{cmol}_{\mathrm{c}} \mathrm{dm}^{-3} ; \mathrm{P}: 2.8 \mathrm{mg} \mathrm{dm}^{-3}$; $\mathrm{K}: 107 \mathrm{mg} \mathrm{dm}{ }^{-3}$; organic matter: $46 \mathrm{~g} \mathrm{~kg}^{-1}$; sand: $136 \mathrm{~g} \mathrm{~kg}^{-1}$; silt: $418 \mathrm{~g} \mathrm{~kg}^{-1}$, and clay: $446 \mathrm{~g} \mathrm{~kg}^{-1}$.

The experimental design was a randomized blocks with four replicates. The treatments were combined in a 2 x 5 factorial, with types of fertilizers application: injected and surface applied; and five sources of N: urea, urea + dicyandiamide (DCD), SS, SS + DCD, and a control treatment with no N fertilization. The application types were arranged in plots of $21 \mathrm{~m} \mathrm{x} 8 \mathrm{~m}$ and the $\mathrm{N}$ sources were allocated in subplots of $4.2 \mathrm{~m} \times 8 \mathrm{~m}$.

The total $\mathrm{N}$ rate applied was $180 \mathrm{~kg} \mathrm{ha}^{-1}$ for maize and $100 \mathrm{~kg} \mathrm{ha}^{-1}$ for wheat, and the amount of slurry was adjusted based on its $\mathrm{N}$ concentration. The SS used in each crop was characterized according to TEDESCO et al. (1995), as follows: maize crop 2012/2013, total N: $3.9 \mathrm{~kg} \mathrm{~m}^{-3}$, ammoniac N: $2.5 \mathrm{~kg}$ $\mathrm{m}^{-3}, \mathrm{P}: 3.0 \mathrm{~kg} \mathrm{~m}^{-3}, \mathrm{~K}: 1.3 \mathrm{~kg} \mathrm{M}^{-3}, \mathrm{pH}: 6.0$, dry mass $58 \mathrm{~g} \mathrm{~kg}^{-1}$; wheat crop 2013: total $\mathrm{N}: 5.7 \mathrm{~kg} \mathrm{~m}^{-3}$, ammoniac $\mathrm{N}: 2.5 \mathrm{~kg} \mathrm{~m}^{-3}$, P: $3.8 \mathrm{~kg} \mathrm{~m}^{-3}$, K: $1.6 \mathrm{~kg} \mathrm{~m}^{-3}$, pH: 6.5, dry mass $44 \mathrm{~g} \mathrm{~kg}^{-1}$; maize crop 2013/2014: total $\mathrm{N}: 5.3 \mathrm{~kg} \mathrm{~m}^{-3}$, ammoniac $\mathrm{N}: 2.7 \mathrm{~kg} \mathrm{~m}^{-3}, \mathrm{P}: 3.1 \mathrm{~kg} \mathrm{~m}^{-3}, \mathrm{~K}: 3.7 \mathrm{~kg} \mathrm{~m}^{-3}, \mathrm{pH}: 6.3$, dry mass $68 \mathrm{~g} \mathrm{~kg}^{-1}$. In treatments with urea as source of $\mathrm{N}$, fertilization was supplemented with $\mathrm{P}$ (triple superphosphate) and $\mathrm{K}$ (potassium chloride) in amounts equivalent to the $\mathrm{P}$ and $\mathrm{K}$ inputs provided by the SS. For both SS and urea, all application of fertilizers was carried out at the crop sowing time. The nitrification inhibitor was Agrotain Plus ${ }^{\circledR}$, which contains $81 \%$ dicyandiamide (DCD), which was mixed with SS and urea at the time of application to the soil at the rate of $10 \mathrm{~kg} \mathrm{ha}^{-1}$.

The SS injection into the soil was performed with an equipment developed by MEPEL® company, composed by a metal tank with a capacity of 4,000 L, with six injection lines spaced apart by $35 \mathrm{~cm}$. The depth of injection was $8 \mathrm{~cm}$ and the mean surface mobilization at the furrows was $11 \mathrm{~cm}$. In the injected urea treatment, the fertilizer was distributed in the furrows opened by the slurry injector and incorporated with hoe in the furrow. The surface application of slurry was carried out with the same 
equipment, with the injection parts suspended above the ground. In the surface application urea was broadcast hand-applied.

Soil samples were collected using an auger in the 0-5, 5-10 and 10-20 cm depths, in composite samples made up of five subsamples in each subplot. In the treatments with fertilizer injection, two subsamples were collected in the injection lines and three between the lines. In the treatments with surface application of fertilizers, samples were randomly collected. The sample collection occurred in the first month after application of fertilizers, in variable interval and duration in each crop, according to the variation of mineral $\mathrm{N}$ concentrations in the soil. The extraction of mineral $\mathrm{N}$ was performed with $\mathrm{KCl}$ $1.0 \mathrm{~mol} \mathrm{~L}^{-1}$ solution, collecting an aliquot for subsequent distillation in semi-micro kjeldhal equipment (TEDESCO et al., 1995).

The results were submitted to analysis of variance and afterwards by Tukey's test $(\mathrm{p}<0.05)$ for mean comparison, analyzing each crop separately, using the statistical system SAS, version 9.1 (2007).

\section{RESULTS AND DISCUSSION}

Results of each variable and crop season were presented according to the analysis of variance considering the main effect of fertilizer and forms of application or interaction between fertilizer and forms of application.

\section{Interaction between fertilizer type and type of application}

The highest $\mathrm{NH}_{4}{ }^{+}$concentrations in the 2012/2013 maize crop season occurred under DCDtreated SS, applied to the surface, one day after fertilization, when compared to the injected application (Table 1). On the 8th day, $\mathrm{NH}_{4}{ }^{+}$concentration was $65 \%$ higher in the treatment SS+DCD injected in relation to the surface applied (Table 1), indicating that the nitrification was delayed, maintaining $\mathrm{N}$ in the form of $\mathrm{NH}_{4}^{+}$, which can be lost by ammonia volatilization, or electrostatically adsorbed to the negative-charged surfaces of clays and other functional groups of soil organic matter (SUBBARAO, 2015). The extension of time in which $\mathrm{NH}_{4}{ }^{+}$remains in the soil can increase its uptake by the plants, improving $\mathrm{N}$ use efficiency.

Vallejo et al. (2005), testing injected and surface application of SS treated with DCD on a clayey soil in Spain, verified that injection of SS+DCD decreased $\mathrm{N}$ losses in the $\mathrm{NO}_{3}{ }^{-}$and $\mathrm{N}_{2} \mathrm{O}$ forms. 
Table 1. Interaction between application form (injected and surface) and types of fertilizer (urea, urea + DCD, SS, SS+DCD and control), for ammonium and nitrate concentrations, during days after fertilization in 2012/2013-maize crop and for ammonium concentrations in 2013-wheat crop and 2013/2014-maize crop, on a Humic Dystrupept soil.

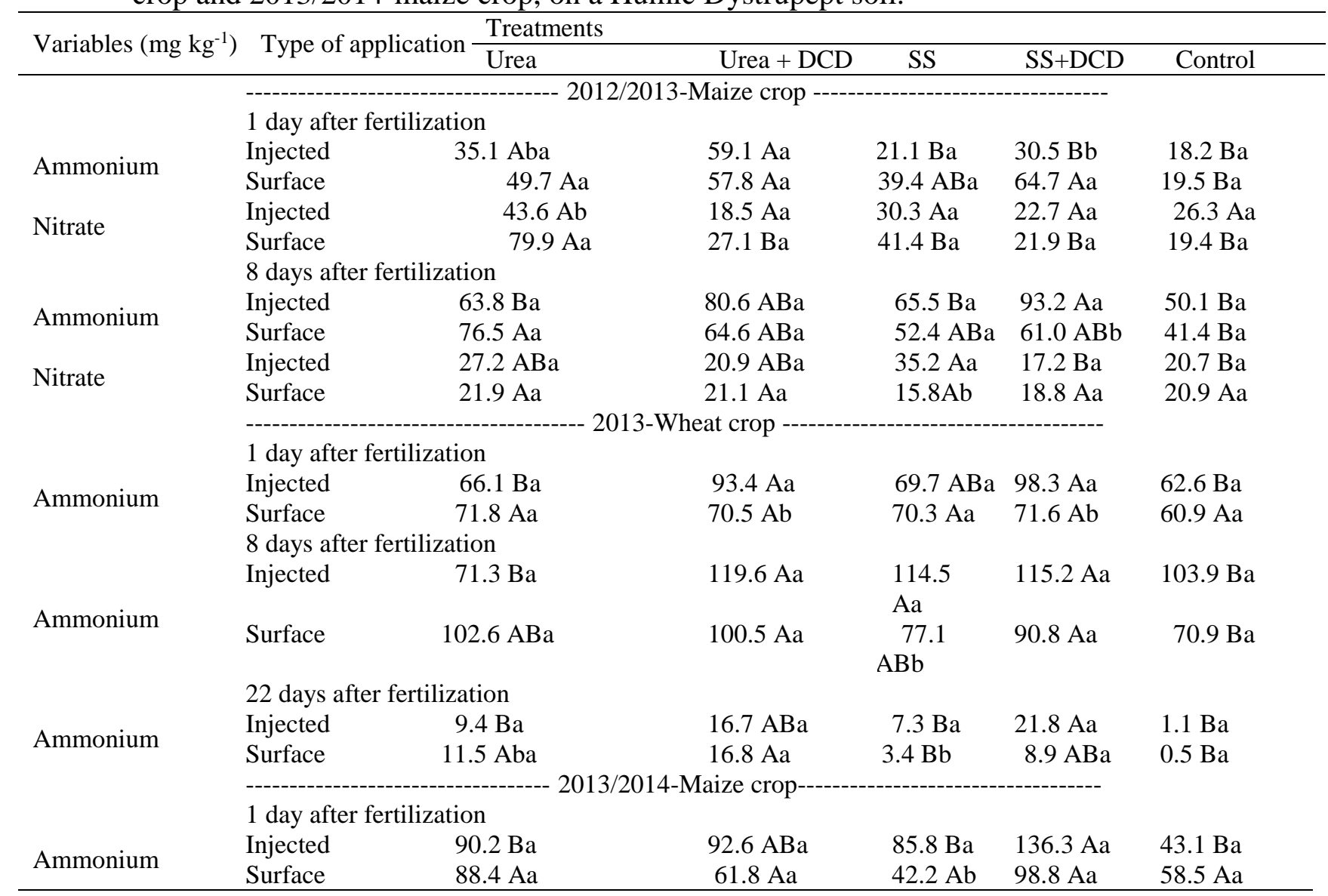
Uppercase letters compare types of fertilizer on the line and lower case letters compare application type in the column.

Surface application of untreated urea increased nitrate concentration $\left(79.9 \mathrm{mg} \mathrm{kg}^{-1}\right)$ one day after fertilization, in relation to the other treatments (Table 1). On the $8^{\text {th }}$ day, $\mathrm{NO}_{3}{ }^{-}$concentration in $\mathrm{SS}+\mathrm{DCD}$ treatment was lower than in untreated SS (Table 1), related to inhibition effect of DCD, reducing nitrification, as noted by Singh \& Verma (2008), who verified efficiency of DCD added to animal manures to reduce $\mathrm{N}$ losses by $\mathrm{NO}_{3}{ }^{-}$leaching.

In the wheat crop (2013), urea + DCD showed a higher $\mathrm{NH}_{4}{ }^{+}$concentration in comparison with urea injected-applied, on the $1^{\text {st }}$ day after fertilization (Table 1). Injected treatments urea and SS treated with DCD, had higher $\mathrm{NH}_{4}{ }^{+}$concentrations than surface applied treatments, on the $1^{\text {st }}$ day after fertilization. In this case, in addition to the inhibitory effect of DCD, injection increased efficiency of $\mathrm{N}$ sources (AITA et al., 2013; AITA et al., 2014), by reducing both nitrification and $\mathrm{NH}_{3}$ volatilization.

On the $8^{\text {th }}$ day after fertilization, SS injection increased $\mathrm{NH}_{4}{ }^{+}$concentrations as compared to the 
surface application, with the same effect observed at 22 days after fertilization (Table 1). Soil injection of DCD-treated urea and SS increased ammonium concentration at 22 days in relation to these untreated fertilizers, producing a lasting inhibitory effect.

Subbarao (2015), reports that the inhibitory action of DCD decreases due to microbial decomposition, which is faster in high-temperature conditions. Although there was no significant correlation between mineral $\mathrm{N}$ concentration and temperature in this work (unpublished data), the duration of DCD effect may have been influenced by temperature.

For the 2013/2014 maize crop, SS injection increased $\mathrm{NH}_{4}{ }^{+}$concentration on the $1^{\text {st }}$ day after application in relation to surface application (Table 1). DCD was effective when mixed with SS and injected into the soil, because in this condition we have the effect of the inhibition of nitrification by the effect of DCD and the effect of maintaining $\mathrm{N}$ in the ammoniacal form, where no losses occur due to volatilization of ammonia as a function of the injection effect of SS.

\section{Main effect of fertilizer}

The addition of DCD to SS increased $\mathrm{NH}_{4}{ }^{+}$concentrations for approximately one week, in the 2012/2013 maize crop, compared to untreated SS (Figure 1a), evidencing the temporary action of DCD in maintaining ammoniac $\mathrm{N}$ for a longer period. Similar effect of DCD to conserve $\mathrm{NH}_{4}{ }^{+}-\mathrm{N}$ form occurred with urea in the $2012 / 2013$ maize crop (Figure 1a), on the $1^{\text {st }}$ and on the $17^{\text {th }}$ day after fertilization. On the $17^{\text {th }}$ day after fertilization, $\mathrm{NH}_{4}{ }^{+}$concentration in DCD-treated fertilizers reached 75 $\mathrm{mg} \mathrm{kg}^{-1}$, and was only $41 \mathrm{mg} \mathrm{kg}^{-1}$ in untreated fertilizers. In the wheat crop, this effect was observed on the $1^{\text {st }}, 8^{\text {th }}$ and $22^{\text {nd }}$ days (Figure 1c) and in the maize crop (2013/2014) only on the $6^{\text {th }}$ day after fertilization (Figure 1c).

Li et al. (2014) report that the addition of DCD in cattle manure applied to an Oxisol in New Zealand decreased nitrification rate. In Brazil, Aita et al. (2013) added DCD to poultry litter in an Ultisol and verified reduction in the nitrification rate of ammoniac N. In an Oxisol, Aita et al. (2014) tested DCD-treated SS and verified a positive effect on delaying nitrification process, allowing a reduction in $\mathrm{N}_{2} \mathrm{O}$ emissions. 

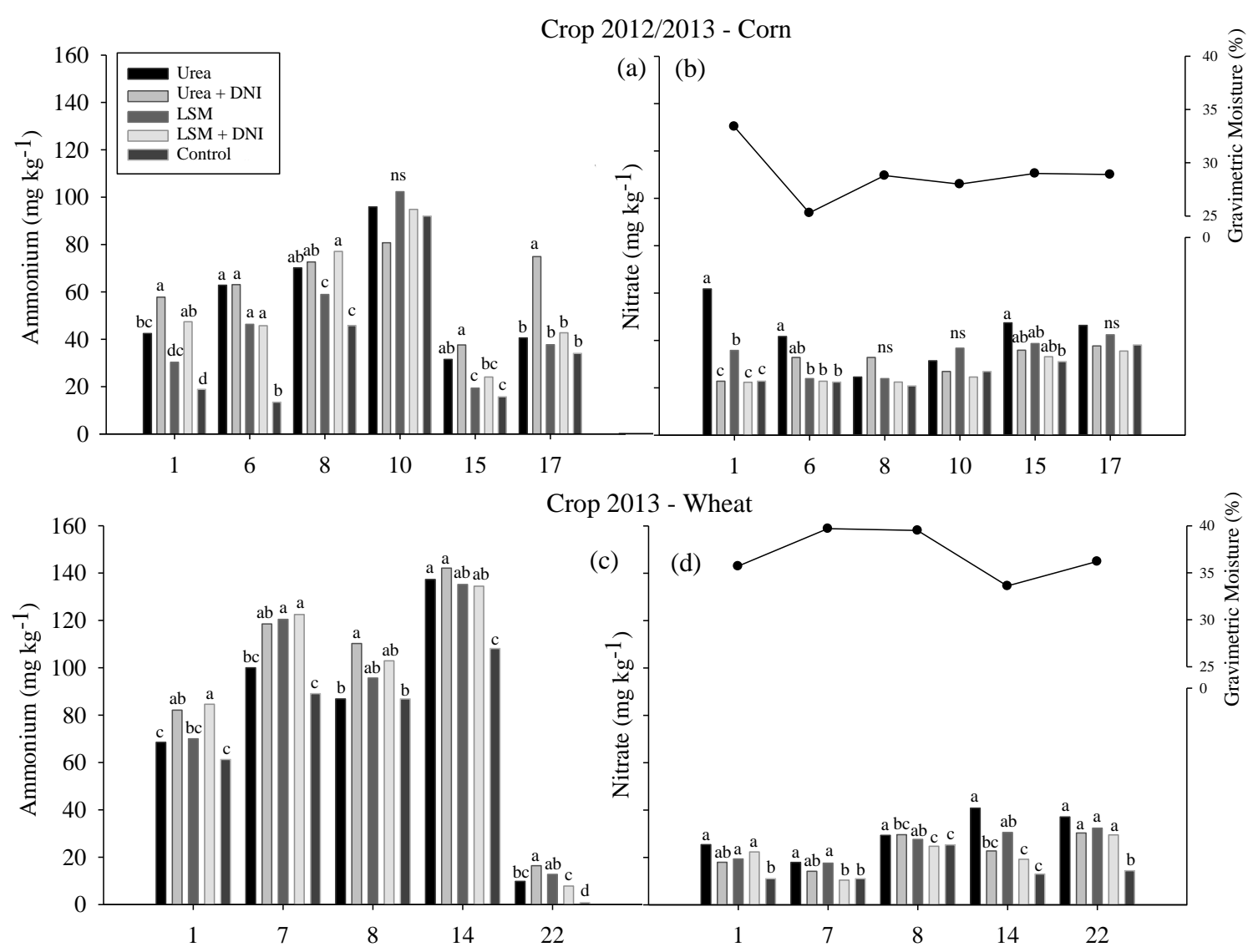

Crop 2013/2014 - Corn

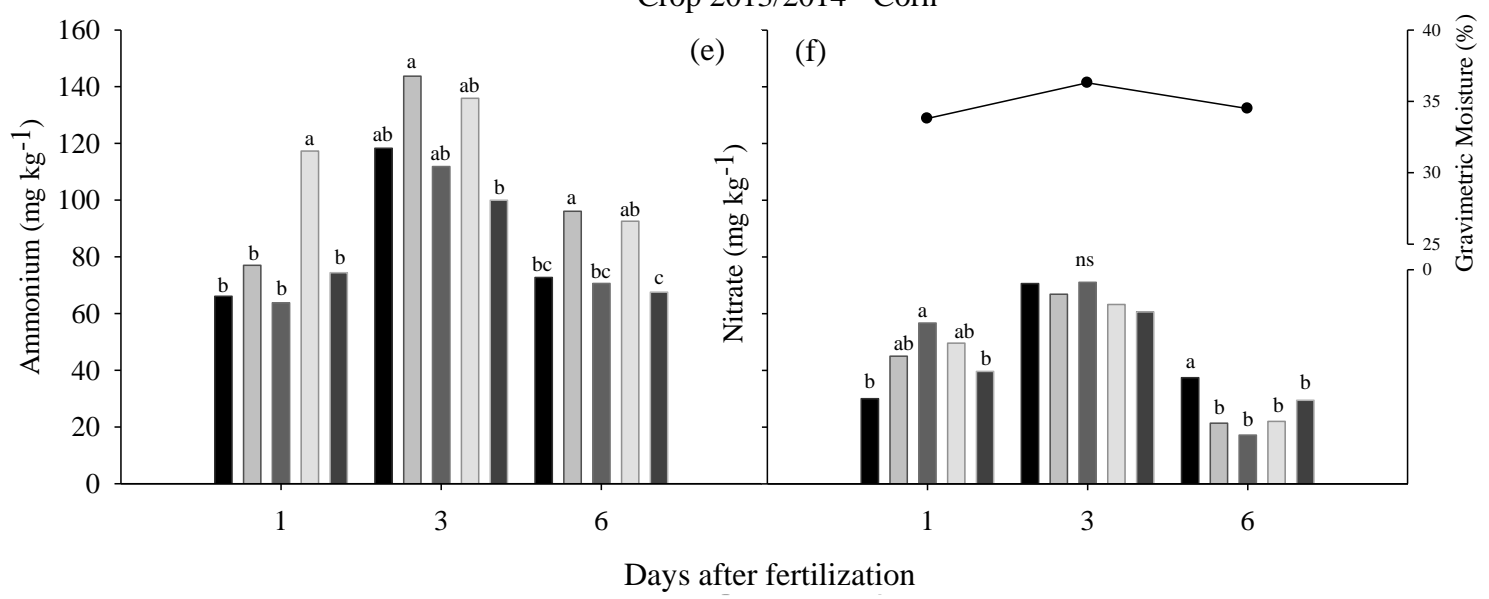

Figure 1. Main effect of type of fertilizer (urea, urea + DCD, SS, SS + DCD and control) on ammonium and nitrate concentrations $\left(\mathrm{m} \mathrm{kg}^{-1}\right)$ in 2012/2013, 2013, and 2013/2014 crops, observed days after fertilization, together with soil gravimetric moisture (\%), on a Humic Dystrupept soil, in the 0-20 cm depth. Lowercase letters compare fertilizers on each day after fertilization. 
It was noted that the inhibitory effect of DCD on N nitrification in SS can occur until the first week of evaluation, whereas in urea this inhibition can be observed for longer ( $22^{\text {nd }}$ day in the 2012/2013 maize crop). This reduced action time of DCD in the manure can be attributed to the greater microbial activity due to the high concentration of easily decomposable organic matter. It was observed that in the wheat crop (winter) the inhibitory action was prolonged in relation to the 2012/2013 crop. The longer permanence of $\mathrm{N}$ in ammonium form has an environmental importance because it reduces nitrate losses by leaching and surface runoff and avoid surface and subsurface water contamination, as well as reduces denitrification and $\mathrm{N}_{2} \mathrm{O}$ emission, which is a potent greenhouse gas.

Low soil $\mathrm{NO}_{3}{ }^{-}$concentrations were observed in urea and SS treatments, both with DCD, in the $2012 / 2013$ crop on the $1^{\text {st }}$ day after fertilization (Figure $1 \mathrm{~b}$ ). On the $6^{\text {th }}$ day of evaluation, $\mathrm{NO}_{3}{ }^{-}$ concentrations were similar under DCD-treated and untreated urea treatments. In the wheat crop it was observed that DCD-treated SS presented the lowest $\mathrm{NO}_{3}{ }^{-}$concentrations in the $7^{\text {th }}, 8^{\text {th }}$ and $14^{\text {th }}$ evaluation days in relation to the untreated SS (Figure 1d). Low $\mathrm{NO}_{3}{ }^{-}$concentrations observed in the wheat crop (Figure 2d) when compared to the other crops (Figures 1b, e, f), can be related to the high soil moisture in the winter growing season (Figure 1d), causing more dilution of soil solution or leaching.

\section{Main effect of the form of application}

The injection of fertilizers in the three crops generally resulted in a higher $\mathrm{NH}_{4}{ }^{+}$concentration (Figures $2 \mathrm{a}, \mathrm{c}, \mathrm{e}$ ), in relation to surface application, which may indicate low risk of $\mathrm{NH}_{3}$ volatilization (AITA et al. 2014). The injection of fertilizers also increased soil nitrate concentrations in the 2012/2013maize and 2013-wheat crops, especially in the first week after application. Studies that report types of application of organic fertilizers (ROCHETTE et al. 2001; FANGUEIRO et al. 2015) indicate that SS injection may present a higher concentration of mineral $\mathrm{N}$ in relation to a surface application, since it can reduce ammonia emissions, as well as increase mineralization rate of the organic $\mathrm{N}$, both from soil and manure. 
Crop 2012/2013 - Corn
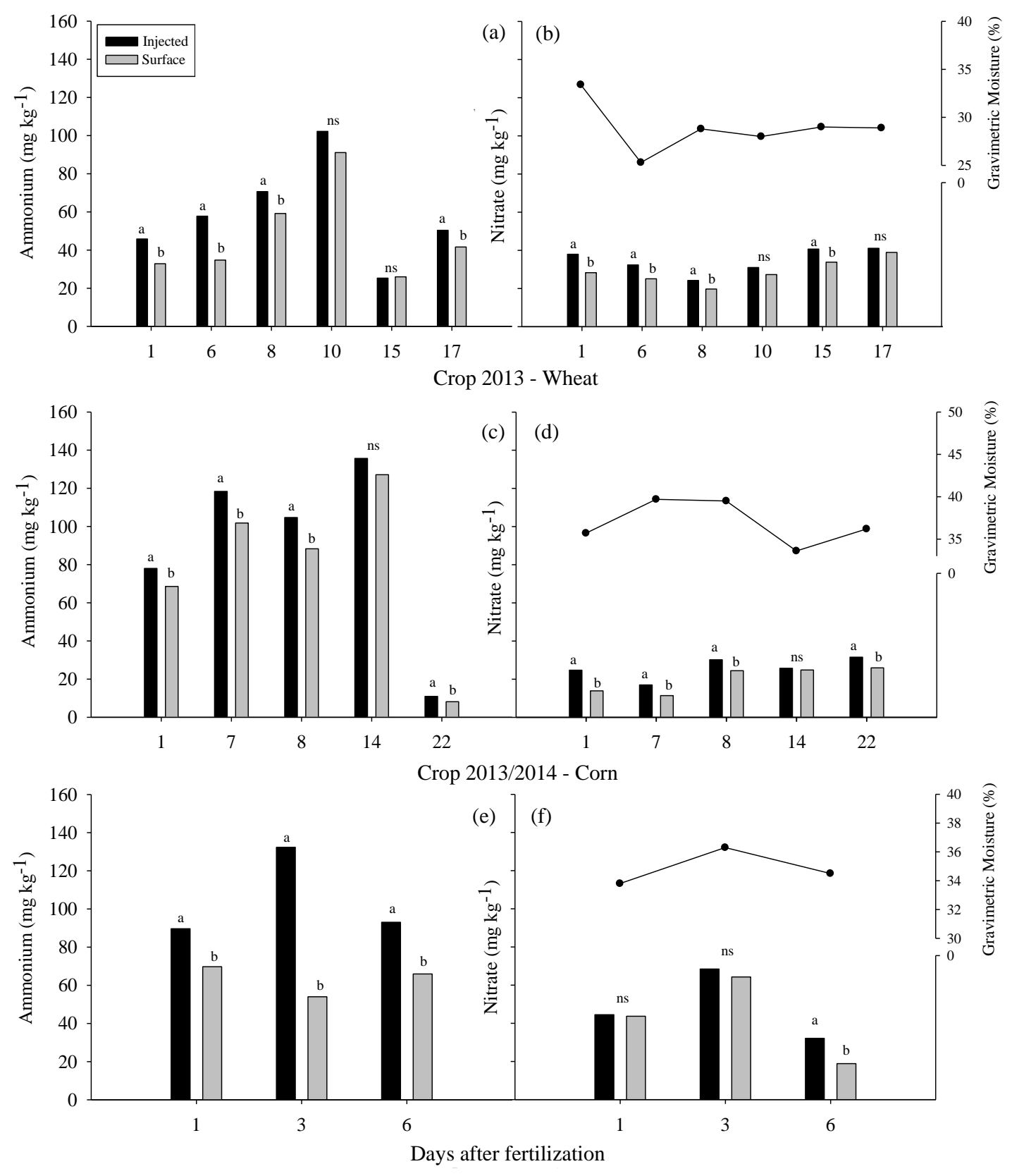

Figure 2. Main effect of application type (injected and surface) on ammonium and nitrate concentrations ( $\mathrm{mg} \mathrm{kg}^{-1}$ ), in 2012/2013, 2013, and 2013/2014 crops, observed days after fertilization, together with soil gravimetric moisture (\%), on a Humic Dystrupept soil, in the 0-20 cm depth. Lowercase letters compare type of application on each day after fertilization. 


\section{CONCLUSION}

The nitrification inhibitor DCD conserves $\mathrm{N}$ in ammonium form and this effect is dependent on the type of fertilization, reaching one week for SS and up to two weeks for urea, which can reduce losses by nitrate leaching and denitrification, but may increase ammonia volatilization, especially in surface application of these fertilizers.

The injection of nitrogen fertilizers increases soil mineral $\mathrm{N}$ concentration in the first week after application, which can indicate low effective losses of ammonia by volatilization.

Although different $\mathrm{N}$ rates in maize and wheat crops, there is no direct effect of fertilizer rates on soil mineral $\mathrm{N}$ concentrations evaluated during three weeks after application.

\section{REFERENCES}

AITA. C.; BALEM. A.; PUJOL. S. B.; SCHIRMANN. J.; GONZATTO. R.; GIACOMINI. D. VARGAS. P. V.; A.; GIACOMINI. S. J. 2013. Redução na velocidade da nitrificação no solo após aplicação de cama de aviário com dicianodiamida. Ciência Rural. Santa Maria. v.43. p.1387-1392. Disponível em: <http://www.scielo.br/pdf/cr/v43n8/a22913cr6217.pdf>.

AITA. C.; GONZATTO. R.; MIOLA. E. C.; ROCHETTE. P.; ANGERS. D. A.; CHANTIGNY. M. H.; PUJOL S. B.; GIACOMINI. D. A.; GIACOMINI. S. J. 2014. Injection of dicyandiamide-treated pig slurry reduced ammonia volatilization without enhancing soil nitrous oxide emissions from no-till corn in Southern Brazil. Journal of Environmental Quality. Madison. v.43. p.789-800. doi: 10.2134/jeq2013.07.0301

DELL. C. J.; KLEINMAN. P. J.; SCHMIDT. J. P.; BEEGLE. D. B. 2011. Low-disturbance manure incorporation effects on ammonia and nitrate loss. Journal Environmental Quality. Madison. v.41. p.928-937. doi: 10.2134/jeq2011.0327

EMBRAPA. Centro Nacional de Pesquisa em solos. Manual de métodos de análise de solo. Rio de Janeiro. 1997. 212p.

EMBRAPA. Centro Nacional de Pesquisa de Solos. Solos do Estado de Santa Catarina. Rio de Janeiro. (2004). (Boletim de pesquisa e desenvolvimento. 46).

FANGUEIRO. D.; SURGY. S.; FRAGA. I.; CABRAL. F.; COUTINHO J. 2015. Band application of treated cattle slurry as an alternative to slurry injection: Implications for gaseous emissions. soil quality. and plant growth. Agriculture Ecosystems \& Environment. Italy. v. 211. p. 102-111, doi:10.1016/j.agee.2015.06.003

GIACOMINI. S. J.; AITA. C. 2008. Cama sobreposta e dejetos líquidos de suínos como fonte de nitrogênio ao milho. Revista Brasileira de Ciência do Solo. Viçosa. v.33. p.195-205. Disponível em: <http://www.scielo.br/pdf/rbcs/v32n1/19.pdf>. Acesso em: 18 Dez, 2014.

LI. J.; SHI. Y.; LUO. J.; ZAMAN. M.; HOULBROOKE. D.; DING. W.; LEAGARD. GHANI. A. 2014. Use of nitrogen process inhibitors for reducing gaseous nitrogen losses from land-applied farm effluents. Biology and Fertility of Soils. Italy. v.50. p.133-145. doi:10.1007/s00374-013-0842-2

MISSELBROOK. T. H.; SMITH. K. A.; JOHNSON. R. A.; PAIN. B. F. 2002. Se-Structures and Environment: Slurry application techniques to reduce ammonia emissions: Results of some UK 
field-scale experiments. Biosystems Engineering. Lomana. v.20. p.313-321. doi: 10.1006/bioe.2001.0017

ROCHETTE. P.; CHANTIGNY. M. H.; ANGERS. D. A.; BERTRAND. N. \& CÔTÉ. D. 2001. Ammonia volatilization and soil nitrogen dynamics following fall application of pig slurry on canola crop residues. Canadian Journal of Soil Science. Ottawa. v.82. p.515-523. doi: 10.4141/S00-044

SAS - Institute INC.SAS 9.1.3 (TS1M3) for Windows Microsoft. 2007. Cary: SAS NC Institute.

SINGH. N. S.; VERMA. A. 2008. The potential of nitrification inhibitors to manage the pollution effect of nitrogen fertilizers in agricultural and other soils: A review. Environmental Practice. Cambridge. v.4. p.266-279.

SUBBARAO. G.V. 2015. Review: Suppression of soil nitrification by plants. Plant Science. Dordrecht. V. 233. p.155-164, doi: 10.1016/j.plantsci.2015.01.012

TEDESCO. M.J.; GIANELLO. C.; BISSANI. C.A.; BOHNEN. H.; VOLKWEISS. S.J. 1995. Análises de solo, plantas e outros materiais. 2.ed. Porto Alegre: Universidade Federal do Rio Grande do Sul. 174p.

VALlEJO. A.; GARCÍA-TORRES. L.; DÍEZ. J. A.; ARCE. A.; LÓPEZ-FERNÁNDEZ. S. 2005. Comparison of $\mathrm{N}$ losses $\left(\mathrm{NO}_{3}{ }^{-} \cdot \mathrm{N}_{2} \mathrm{O}\right)$ from surface applied. injected or amended (DCD) pig slurry of an irrigated soil in a Mediterranean climate. Plant Soil. Dordrecht. v.272. p.313-325, doi: 10.1007/s11104-004-5754-3

ZAMAN. M.; BLENNERHASSETT. J. D. 2010. Effects of the different rates of urease and nitrification inhibitors on gaseous emissions of ammonia and nitrous oxide. nitrate leaching and pasture production from urine patches in an intensive grazed pasture system. Agriculture, Ecosystems \& Environment. Cambridge. v.136. p.236-246, doi:10.1016/j.agee.2009.07.010

Received in: May 25, 2016 Accepted in: June 08, 2018 